\title{
ANALYSIS OF DI-N-BUTYL PHTHALATE (DBP) RESIDUE IN COMMERCIAL FOOD PACKAGING FROM RECYCLED PAPER AND ITS MIGRATION INTO FOOD SIMULANT
}

\section{ANALISIS KANDUNGAN DI-N-BUTIL PTALAT (DBP) PADA KEMASAN KERTAS DAUR ULANG SERTA MIGRASINYA KE DALAM SIMULAN PANGAN}

\author{
Made Gayatri Anggarkasih"1), Nancy Dewi Yuliana ${ }^{1 *}$, Yane Regiyana), \\ Muhammad Yusram Massijaya ${ }^{2)}$, Slamet Budijanto ${ }^{1)}$ \\ ${ }^{1)}$ Department of Food Science and Technology, Bogor Agricultural University, \\ IPB Darmaga Campus, Bogor, Bogor 16680, Indonesia \\ Email :nancy_dewi@ipb.ac.id; juliana.luthfia@gmail.com \\ ${ }^{2)}$ Department of Forest Product, Bogor Agricultural University, Indonesia \\ Makalah: Diterima 13 Februari 2018; Diperbaiki 10 Juni 2018; Disetujui 11Agustus 2018
}

\begin{abstract}
Ptalat adalah senyawa yang ditemukan dalam zat aditif yang sering ditambahkan ke dalam bahan kemasan berbasis kertas daur ulang. Zat yang berpotensi berbahaya yang ada dalam kertas daur ulang terkandung dalam residu tinta cetak, pernis, perekat dan zat lainnya. Makanan yang kontak langsung dengan kemasan kertas daur ulang dapat mengandung diisopropil-napatalene (DIPN), benzofenon, terfenil terhidrogenasi, amina aromatik primer, poliaromatik hidrokarbon (PAH), dan ptalat. Ptalat dapat bermigrasi dari kemasan ke dalam makanan, terutama untuk produk pangan berlemak. Salah satu jenis ptalat yaitu dibutil ptalat (DBP) dilaporkan dapat mengganggu sistem endokrin. Pada dosis tinggi, DBP telah terbukti merusak sistem reproduksi tikus. Penelitian ini bertujuan untuk mengidentifikasi dan mengkuantifikasi DBP dari kemasan makanan berbasis daur ulang (dupleks) dan migrasinya ke dalam simulan pangan. Metode yang digunakan yaitu ekstraksi dengan pelarut yang dibantu ultrasonik (USE), diikuti dengan analisis kromatografi gas - spektrometri massa $(G C-M S)$. Metode yang dikembangkan telah divalidasi, dengan nilai linearitas $\left(R^{2}\right)$ dari 0,999 , rentang akurasi 89,98\% - 102\%, batas deteksi (LOD) dan batas kuantifikasi (LOQ) berturut-turut sebesar 0,04 mg/L dan $0,06 \mathrm{mg} / \mathrm{L}$. Hasil analisis DBP dari lima kertas dupleks komersial berbeda nyata pada kisaran 1,7 hingga 5,8 $\mathrm{mg} / \mathrm{kg}$. Tingkat migrasi yang diukur dari kontak langsung antara kertas dan etanol 95\% sebagai simulantpangan selama 2 jam pada suhu $40^{\circ} \mathrm{C}$ adalah $4,7 \mathrm{mg} / \mathrm{dm}^{2}$. Migrasi DBP melebihi nilai migrasi spesifik yang ditetapkan pada EU No. 10/2011 (0,3 mg/kg atau 0,05 mg/d $\left.{ }^{2}\right)$. Hasil tersebut menunjukkan bahwa penggunaan kertas daur ulang sebagai kemasan primer produk pangan tidak dianjurkan, terutama untuk pangan berlemak.
\end{abstract}

Kata kunci: Dibutil ptalat, kertas daur ulang, GC-MS, simulan pangan, migrasimilk

\section{ABSTRAK}

Phthalates are compounds found in additives that frequently added into recycled paper-based packaging material. Potentially harmful substances present in the recycled paper comprise the residues of printing inks, varnishes, adhesives and other substances. Foods that are in direct contact with recycled paper packaging containing diisopropyl-naptalene, benzophenone, terphenyl hydrogenated, primary aromatic amine, polyaromatichydrocarbon (PAH) and phthalates. Trace amounts of phthalates can leach out of food packaging and get into the food, especially for fat rich-food products. One of phthalates, di-n-butyl phthalate (DBP) was reported as endocrine disrupter. In high doses, DBP has been shown to harm the reproductive system of rodents. This research aimed to identify and quantify DBP from recycled paper-based food packaging and its migration into food simulant. The method based on ultrasound-assisted solvent extraction (USE) followed by gas chromatography-mass spectrometry (GC-MS) analysis. The developed method was validated. It had linearity value $\left(\mathrm{R}^{2}\right)$ of 0.999 , recovery percentage of $91.4 \%-103.6 \%$, limit of detection (LOD) and limit of quantification (LOQ) at $0.04 \mathrm{mg} / \mathrm{L}$ and $0.06 \mathrm{mg} / \mathrm{L}$, respectively. Analyses of DBP from five commercial duplex papers were found to vary from the range of 1.7 to $5.8 \mathrm{mg} / \mathrm{kg}$. Migration rate, which was measured from direct contact between the papers and ethanol $95 \%$ as food simulant for 2 hours at $40^{\circ} \mathrm{C}$ was $4.7 \mathrm{mg} / \mathrm{dm}^{2}$. The DBP migration exceeded Commission Regulation (EU) No. $10 / 2011\left(0.3 \mathrm{mg} / \mathrm{kg}\right.$ or $\left.0.05 \mathrm{mg} / \mathrm{dm}^{2}\right)$. These results indicate that the use of recycled paper as the primary food packaging is not recommended, especially for fatty food.

Keywords: Di-n-butyl phthalate, recycled paper, GC-MS, food simulant, migration

\section{INTRODUCTION}

Almost $90 \%$ of commercial paper boards are made from recycled papers. Recycled paper frequently used as food packaging material for various food products. A thicker paper called paperboard is made from recycled paper and often contains blemishes and impurities fromthe original

*Penulis Korespodensi 
paper, which makes unsuitablefor direct food contact (Marsh and Betty, 2007). In fact, recycled paper food packaging commonly used to pack dry food products such as sugar, salt, flour, rice, pasta, and cereal (Binderup et al., 2002; Suciu et al., 2013). Recycled paper is even often used as food primary packaging (Fitria et al., 2018). There is not so much awareness yet about the health risk of using this recycled paper as primary food packaging despite several studies indicated that we should pay more attention to this fact.

Recycled paper is made from waste paper which is processed in such a way to obtain a sheet of paperback. Hazardous contaminants on recycled paper come from printing ink residues, varnishes, adhesives and other materials used in the recycled paper manufacturing process (Jamnicki et al., 2012). According to Zhang et al. (2008), there are two types of contaminants found in recycled paperboard packaging, namely di-butyl phthalate/DBP $(0,14-55$ $\mathrm{mg} / \mathrm{kg}$ ) and 2,6-diisopropyl naphthalene/DIPN $(0,09-20 \mathrm{mg} / \mathrm{kg})$. In addition, a number of studies have found pthalate content in various types of fatty or oily foods (Wenzl, 2009). DBP is the highest concentration of phthalate in recycled paper which is $628 \mathrm{mg} / \mathrm{kg}$ (Vapenka et al., 2016). For recycled paper, phthalates could also be carried over from the inks and adhesives on previous materials due to an incomplete removal during the recycling process (Cao, 2010).

Phthalates are known to cause endocrine effects in mice. According to Lara et al. (2017) that DBP exposure to pregnant mice causes reproductive disorders in male off spring such as testicular dysgenic syndrome (TDS). Tolerable Daily Intake (TDI) for DBP is $0.01 \mathrm{mg} / \mathrm{kg}$ body weight per day based on toxicology studies (EFSA, 2005). Exposure to phthalates primarily due to migration from packaging to food products needs to be a concern, but information on the content of phthalate and its migration on duplex paper are not widely available in Indonesia. Until now there is no standard method for DBP content analysis especially on recycle paper so that it can be used analytical method with validation test parameter.

The analysis of contaminants (such as phthalate) can be considered as two-stage procedure which includes the extraction followed by their identification and quantification. Various method of extraction of phthalates has been published. During the last few years, several methods were proposed for the determination of phthalates by gas chromatography (GC) preceded by different preconcentration techniques such as cold fiber solid phase micro extraction (CF-SPME) for benzyl butyl phthalate (BBP) and di-butyl phthalate (DBP) analysis on plastic container (Moreira et al., 2014); liquid-liquid extraction (LLE) for dimethyl phthalate (DMP), bis (2-ethylhexyl) phthalate (DEHP), DBP, and BBP on milk samples (Milojkovic et al., 2015); ultrasound assisted solvent extraction (UAE) for all contaminants on paper food packaging such as benzophenone, di-isobutyl phthalate (DIBP) and DBP (Vapenka et al., 2016). Suciu et al. (2013) used soxhlet extraction for bisphenol A (BPA), DEHP, nonylphenol mono-ethoxylate (NMP) and nonylphenol diethoxilate (NDP) on recycled paper food packaging. In addition, on recycled food paper, Parigoridi (2014) has conducted an analysis to determine vary type of contaminants that contained therein using UAE extraction method with dichloromethane.

Di-butyl phthalate (DBP) is a compound with low polarity, thus it is soluble in relatively non polar solvent such as hexane and dichloromethane. Thus, we used dichloromethane to extract DBP from our samples. In this study we used UAE at room temperature to prevent evaporation of semi-volatile components. UAE is a conventional method for solid samples extraction in many laboratories today because the procedure is simple, inexpensive, and fast as compared to other methods such as soxhlet (Wei et al., 2014).

Fatty and oily food primarily contaminated with phthalates due to their lipophilic character. Hence human intake of phthalates may originate from many foods particularly fatty foods (Milojkovics et al., 2015). There is a special interest to study the possibility of phthalates (DBP) on recycled paper packaging and its migration because recycled paper is widely used to pack various fatty/oily foods, especially in Indonesia. To simplify the migration analysis, food samples can be replaced with food simulants according to desired type of food. At present, there is no harmonized direction on (1) regulation of paper based material packaging (including recycled paper) intended for direct food contact; (2) standard method to identify contaminants including phthalates on paper food packaging. The aim of this research was validated a method to identify and quantify DBP in food packaging made from recycled paper furthermore its migration to fatty food stimulant.

\section{MATERIALS AND METHODS}

\section{Materials}

Chromatography grade methanol, dichloromethane, acetone, ethanol 95\%, and sodium sulphate anhydrous were obtained from Merck (Darmstadt, Germany). Standard of di-n-butyl phthalate (DBP) was from Sigma Aldrich (Saint Louis, USA). All solvents and reagents were of analytical grade. In this study we used commercial recycled paperboard (duplex paper) commonly used as food packaging materials. Duplex papers were obtained from five manufacturers in Indonesia and were labeled as A, B, C, D and E. Virgin paper was used as a control. All samples were prevented from contact with any kind of plastic materials. 


\section{Extraction and Determination Method (Modified From Parigoridi, 2014)}

To avoid phthalates contamination, all glass wares used in this study were washed with acetone and dried overnight before use. To ensure the efficiency of DBP extraction, samples were cut into small pieces $(5 \mathrm{~mm} \times 5 \mathrm{~mm})$. Approximately $175 \mathrm{mg}$ samples were extracted with $10 \mathrm{~mL}$ dichloromethane in the ultrasonic bath (Bransonic, Danbury, USA) at $25^{\circ} \mathrm{C}$ for $30 \mathrm{~min}$. The mixture was filtered and washed with $1 \mathrm{~mL}$ of dichloromethane twice. The organic phase was evaporated using rotary evaporator (Buchi, Flawil, Switzerland) at $40{ }^{\circ} \mathrm{C}$ followed by flushing under nitrogen gas till dryness. The extract was re-dissolved in $1 \mathrm{~mL}$ of methanol and stored in tightly screwed cap vials for further analysis using GC MS (Shimadzu QP 2010 plus). The analysis was done in triplicates. DBP stock solution was prepared at a concentration of 1000 $\mathrm{mg} / \mathrm{L}$ and the working solution was prepared at 5 $\mathrm{mg} / \mathrm{L}$ in methanol. Calibration solutions were prepared at DBP concentration of $0.05 ; 0.1 ; 0.25 ; 1$ and $1.5 \mathrm{mg} / \mathrm{L}$. Spiking solution for recovery test was prepared at DBP concentration of $1 \mathrm{mg} / \mathrm{L}$. Modification was carried out on the drying of the organic phase. In this research, a rotary evaporator was used after the extraction process to evaporate most of the dichloromethane, followed by drying under nitrogen to all the dry solvents, and then redissolved by using methanol.

\section{Method Validation}

Quantitative determination of surrogates was done by injecting the appropriate amount of sample into GC-MS using the external standard method. External standards of DBP were prepared in the concentration range of $0.05-1.5 \mathrm{mg} / \mathrm{mL}$ and a calibration curve was then created. The accuracy test was done with the recovery experiments using virgin paperboard materials fortified by $1.00 \mathrm{~mL}$ of $1 \mathrm{mg} / \mathrm{L}$ DBP standard solution. Extraction was conducted as described previously in extraction methods. The recovery result must be in a range of $80-110 \%$ (AOAC, 2012). Recovery is defined as the ratio of the observed result to the expected result expressed as a percentage (APVMA, 2004). Percentage of recovery was calculated using equation 1 .

$\%$ Recovery $=\left[\mathrm{C}_{\mathrm{f}}-\mathrm{C}_{\mathrm{A}}\right] / \mathrm{C}^{*} \mathrm{~A} \times 100 \%$

Where $\mathrm{C}_{\mathrm{f}}$ is the DBP concentration on spiked virgin paper $(\mathrm{mg} / \mathrm{L}), \mathrm{C}_{\mathrm{A}}$ is the DBP concentration on virgin paper $(\mathrm{mg} / \mathrm{L})$, and $\mathrm{C}^{*} \mathrm{~A}$ is the concentration of DBP spiking solution $(\mathrm{mg} / \mathrm{L})$. Limit of detection (LOD) and limit of quantification (LOQ) determination were done by injecting $0.05 \mathrm{mg} / \mathrm{L}$ DBP standard solution six times. LOD and LOQ were estimated using equations (2) and (3) based on APVMA (2004).

$\mathrm{LOD}=\mathrm{X}+(3 \times \mathrm{SD})$
$\mathrm{LOQ}=\mathrm{X}+(10 \mathrm{x}$ SD $)$

Where $\mathrm{X}$ is the mean respond of DBP concentrations $(\mathrm{mg} / \mathrm{L}), \mathrm{SD}$ is the standard deviation of the respond.

\section{Migration Test}

EU Regulation 82/711/EEC described the migration test and specific food simulants to be used based on the type of food being tested. The focus of this research was to measure the migration of DBP into fatty food by simulant $\mathrm{D}$.

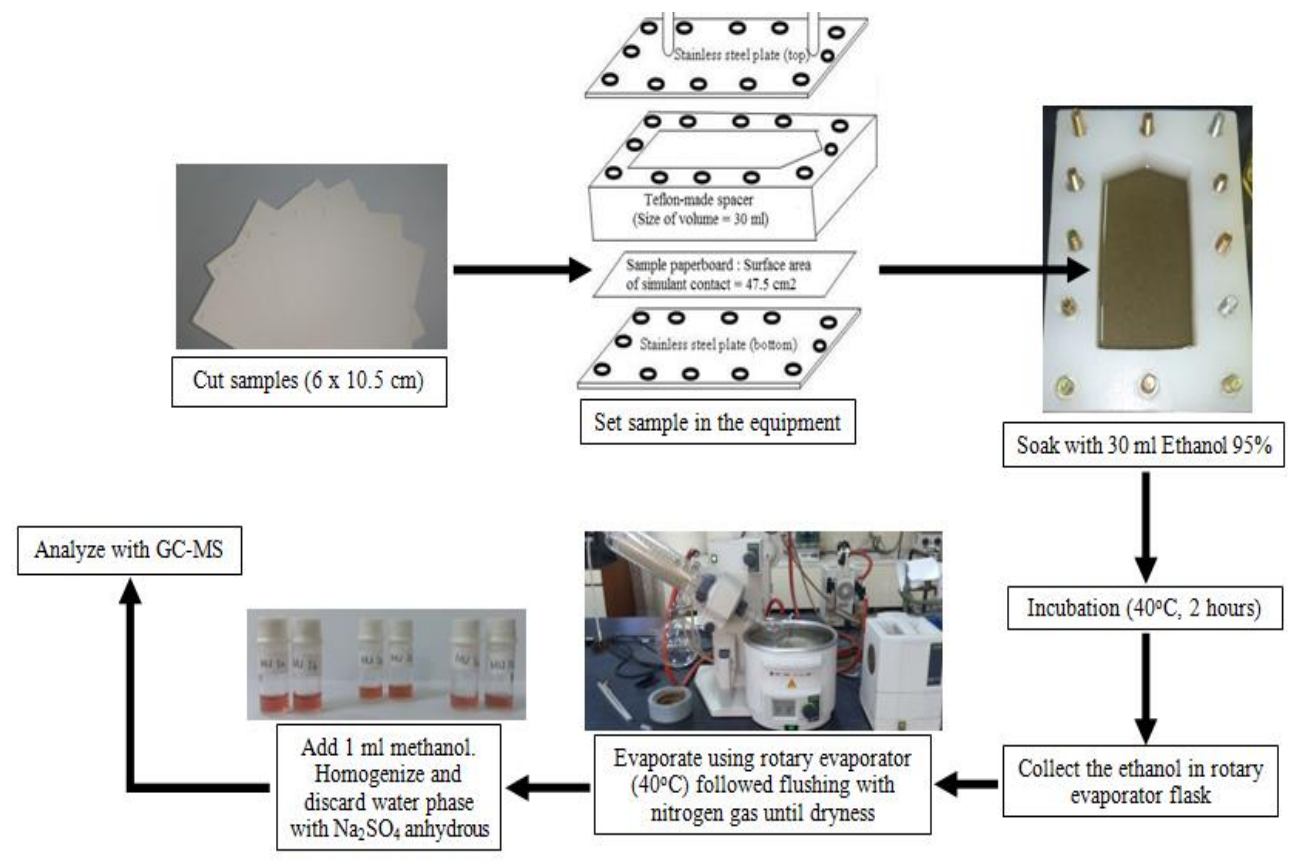

Figure 1. Flowchart for the migration test of DBP 
According to the EU 82/711/EEC, when the use of olive oil as a simulant D2 is not suitable for use in the method performed, it can be replaced with other materials such as isooctane, modified polyphenylene oxide (MPPO), and ethanol 95\%. In this study, DBP was extracted with dichloromethane which is miscible with olive oil. Therefore, we replaced it with ethanol 95\%. Migration test was performed by using single-cell migration method (modification of Pace and Hartman, 2010). Duplex papers was cut $6 \times 10.5 \mathrm{~cm}$ and then inserted into test equipment as shown in Figure 1 (modified from Pace and Hartman, 2010). During the test, the paper was soaked with $95 \%$ ethanol and incubated at $40^{\circ} \mathrm{C}$ for 2 hours. The area which was fully exposed to $95 \%$ ethanol was $47.5 \mathrm{~cm}^{2}$. At the end of the test, ethanol was evaporated with rotary evaporator followed by flushing with nitrogen gas until dryness. It was dissolved in $1 \mathrm{~mL}$ of ethanol to be analyzed by GC-MS. DBP migration values were estimated using equations (4) and (5).

DBP migration $\left(\mathrm{mg} / \mathrm{dm}^{2}\right)=\left[\mathrm{Q}_{\mathrm{f}} / \mathrm{A}\right] \times 10^{2}$

$\%$ migration $=[\mathrm{M} \times 100] / \mathrm{IC}$

Where $Q f$ is DBP concentration in food simulant $(\mathrm{mg} / \mathrm{kg}), A$ is exposed surface area of sample by food simulant $\left(\mathrm{cm}^{2}\right), M$ is DBP migration value $\left(\mathrm{mg} / \mathrm{dm}^{2}\right)$ and $I C$ is DBP initial concentration of sample $\left(\mathrm{mg} / \mathrm{dm}^{2}\right)$.

\section{Instrumentation and GC-MS parameters}

Chromatographic analysis was performed with GC-MS (Shimadzu QP 2010 Plus gas chromatograph), equipped with the data analysis station Shimadzu GC-MS Real Time Analysis. The column used for analysis was Crossbond® Rtx 5 MS-type (5\% diphenyl, 95\% dimethyl polysiloxane; $30 \mathrm{~m} \times 0.25 \mathrm{~mm}$ i.d. $\times 0.25 \mu \mathrm{m}$ film thickness) equivalent with DB-5MS. As a carrier gas, ultra high purity helium was used at a constant flow rate of 0.8
$\mathrm{mL}$ per minute. Injection temperature is $250^{\circ} \mathrm{C}$, with $1 \mathrm{~mL}$ injection volume as in the split less mode and $1 \mathrm{~min}$ as a sampling time. The GC-MS oven temperature was maintained at $100{ }^{\circ} \mathrm{C}$ (holding time 2 minutes), then increased at a rate of $6^{\circ} \mathrm{Cper}$ minute until $320^{\circ} \mathrm{C}$ and remained constant for 3 minutes. The detector temperatures were $230{ }^{\circ} \mathrm{C}$ (ion source) and $250{ }^{\circ} \mathrm{C}$ (interface) mode with electron impact (EI) at $70 \mathrm{eV}$. The compound was identified in total ion monitoring (TIC) mode with $\mathrm{m} / \mathrm{z}$ range at 29 450. Peak identification was performed by comparing retention time and mass spectra with Wiley's compound library.

\section{Statistical Analysis}

The level of variation between DBP concentrations among five samples was evaluated using ANOVA (SPSS 17.0 software) at a significance level of $\mathrm{P}<0.05$ binned with the Duncan test.

\section{RESULTS AND DISCUSSION}

\section{Validated Method}

From linearity test, we obtain $\mathrm{R}^{2}$ value of 0.999 which indicated good linearity between DBP concentration and its respected area responses. The result fulfilled AOAC standard (AOAC, 2012) which requires $R^{2}>0.99$. The obtained equation was $\mathrm{y}=634525 \mathrm{x}+2088$, where $y$ is area response and $x$ is the concentration of DBP standard. Calibration curve was linear from DBP concentration range of 0.05-1.5 mg/L. Chromatogram of $1 \mathrm{mg} / \mathrm{L}$ DBP standard showed in Figure 2. The retention time of DBP was 20.7 minutes. The measured slope should demonstrate a clear correlation between response and analyte concentrations. The results should not show a significant deviation from linearity, which is taken to mean that the correlation coefficient, $\mathrm{R}$ > 0.99 (APVMA, 2004).

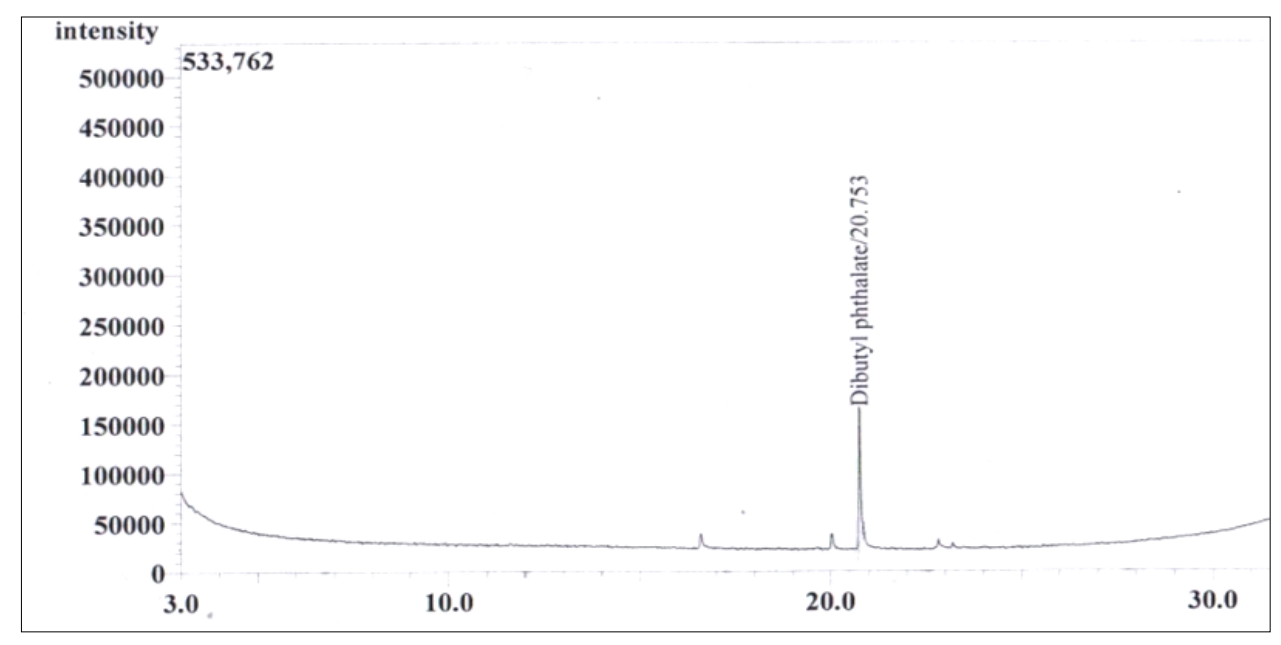

Figure 2. Chromatogram of $1 \mathrm{mg} / \mathrm{L} \mathrm{DBP}$ standard 
The recovery percentage of the investigated DBP showed in Table 1. The results indicate that a very satisfactory recovery for DBP was obtained. The expected recovery depends on the sample matrix, the sample processing procedure and on the analyte concentration. The mean recovery was 95.18 $\%$, it was in the range $80-110 \%$ for the analyte concentration of $10 \mathrm{ppm}$ to $100 \mathrm{ppb}$ (AOAC, 2012). In this result, \% recovery shows that extraction method and GC-MS instrumentation were suitable for DBP analysis. A minimum of 5 replicate sample determinations should be made together with a simple statistical assessment of the results, including the percent relative standard deviation (RSD). In Table 1, RSD value was in the range of AOAC recommendation which is $5-15 \%$. These results showed that the precision of the method is acceptable. The precision of an analytical procedure is usually expressed as the variance, standard deviation or coefficient of variation of a series of measurements (APVMA, 2004). RSD 5.1\% also represented a good repeatability of the method

The limit of detection (LOD) and the limit of quantification (LOQ) measurement were done by injecting $0.05 \mathrm{mg} / \mathrm{L} \mathrm{DBP}$ standard for 6 replications. LOD of an analytical procedure is the lowest amount of an analyte in a sample that can be detected, but not necessarily quantitated as an exact value, while
LOQ is the lowest amount of the analyte in the sample that can be quantitatively determined with defined precision under the stated experimental conditions. LOD and LOQ values were shown in table 2 which indicated that GC-MS used in this study could detect DBP at minimum concentration of $0.04 \mathrm{mg} / \mathrm{L}$ (40 ppb) and could quantify DBP at minimum concentration of $0.06 \mathrm{mg} / \mathrm{L}(60 \mathrm{ppb})$.

In chromatography, besides this signal-tonoise method, LOD can be determined by the standard deviation of the response based on the standard deviation of the blank (Huber, 2007). In this study, value of 0.0025 is the result of the calculation of the blank response standard deviation which shows the results of measuring the magnitude of the analytical background response is performed by injecting an appropriate concentration DBP standard as a blank sample. The quantitation limit is generally determined by the analysis of samples with known concentrations of analyte and by establishing the minimum level at which the analyte can be quantified with acceptable accuracy and precision. In table 2, the calculated relative standard deviation (RSD) 7.7182 shows the percentage of the precision of six repetitive injections is plotted against the analyte amount. The amount that corresponds to the previously defined required precision is equal to the limit of quantitation (Huber, 2007).

Table 1. Recovery ppercentage of the investigated DBP

\begin{tabular}{ccccc}
\hline Replicates & $\begin{array}{c}\text { Spiking } \\
\text { concentration } \\
(\mathbf{m g} / \mathbf{L})\end{array}$ & $\begin{array}{c}\text { Virgin paper } \\
(\mathbf{m g} / \mathbf{L})\end{array}$ & $\begin{array}{c}\text { Spiked Virgin } \\
\text { paper (mg/L) }\end{array}$ & \% Recovery \\
\hline 1 & 1.0160 & 0.0630 & 1.0712 & 99.22 \\
2 & 1.0160 & 0.0970 & 1.0121 & 90.06 \\
3 & 1.0160 & 0.0717 & 1.0275 & 94.08 \\
4 & 1.0160 & 0.2741 & 1.3104 & 102.0 \\
5 & 1.0160 & 0.1604 & 1.0747 & 89.98 \\
6 & 1.0160 & 0.1324 & 1.1051 & 95.75 \\
\hline Mean & & & 95.18 \\
Standard Deviation (SD) & & & 4.85 \\
\% RSD & & & 5.10 \\
\hline
\end{tabular}

Table 2. LOD and LOQ values of DBP analysis (mg/L)

\begin{tabular}{ccc}
\hline Replicates & $\begin{array}{c}\text { Injected DBP Standard } \\
(\mathbf{m g} / \mathbf{L})\end{array}$ & $\begin{array}{c}\text { Measured concentration } \\
(\mathbf{m g} / \mathbf{L})\end{array}$ \\
\hline 1 & 0.0508 & 0.0318 \\
2 & 0.0508 & 0.0353 \\
3 & 0.0508 & 0.0323 \\
4 & 0.0508 & 0.0277 \\
5 & 0.0508 & 0.0325 \\
6 & 0.0508 & 0.0330 \\
\hline Mean( $\mathrm{x})$ & & 0.0321 \\
Standard deviation (SD) & & 0.0025 \\
$\%$ RSD & & 7.7182 \\
LOD (mg L-1) & & 0.0395 \\
LOQ (mg L-1) & & 0.0568 \\
\hline
\end{tabular}




\section{Determination of Di-Butyl Phthalate In Recycled Paperboard}

The summary of DBP content in virgin and recycled paperboards was shown in Table 3 . The content of DBP between samples were found to be significantly different with the lowest levels of 1.7 $\mathrm{mg} / \mathrm{kg}$ found in sample B and the highest levels of $5.8 \mathrm{mg} / \mathrm{kg}$ found in sample C. All recycled paper had significantly higher DBP concentration as compared to virgin paper $(p<0.05)$. Papers with various grammage do not affect the contaminant content of the paper, but paper made with recycled fibers has a higher content. Vapenka et al. (2016) reported that recycled packaging paper contains DBP up to 628 $\mathrm{mg} / \mathrm{kg}$.

Table 3. Levels of DBP in paperboard samples*

\begin{tabular}{|c|c|c|}
\hline $\begin{array}{c}\text { Samples } \\
\text { codes }\end{array}$ & $\mathbf{N}$ & $\begin{array}{c}\text { DBP Concentration } \\
\left(\mathrm{mg} \mathrm{kg}^{-1}\right)\end{array}$ \\
\hline $\mathrm{A}$ & 3 & $2.2331 \pm 0.44^{\mathrm{ab}}$ \\
\hline $\mathrm{B}$ & 3 & $1.7154 \pm 0.43^{\mathrm{ab}}$ \\
\hline $\mathrm{C}$ & 2 & $3.8964 \pm 2.20^{\mathrm{c}}$ \\
\hline $\mathrm{D}$ & 2 & $3.2361 \pm 0.61^{\mathrm{ab}}$ \\
\hline $\mathrm{E}$ & 2 & $1.7751 \pm 0.50^{\mathrm{ab}}$ \\
\hline Virgin paper & 3 & $0.4407 \pm 0.10^{\mathrm{a}}$ \\
\hline
\end{tabular}

Extraction process is the most important part in the analysis of DBP content of the samples. The use of appropriate extraction methods can provide appropriate analysis results. The use of extraction methods with UAE is considered sufficient to provide good analysis results, it can be seen from the validation of methods where the value of recovery between $89.98-102 \%$. The same was reported by Song et al. (2002) where USE was effective for extracting non-volatile compounds such as anthracene, di-methyl phthalate, and methyl stearate. Several factors that influence phthalate extraction are sample preparation, type and volume of solvent, agitation, and extraction time (Milojkovic et al., 2015). Dichloromethane is suitable for extracting DBP because of its non-polar solvent. Parigoridi et al. (2014) reported that dichloromethane had the best ability to extract various contaminants from recycled paper while compared with hexane and ethanol. The extracted analyte of the samples further identified with GCMS.

GC-MS is a method that combines the features of gas-liquid chromatography and mass spectrometry to identify different substances within a test sample. Figure 3 showed the representative chromatograms of virgin paper and recycled papers from five different manufacturers. The lowest peak of DBP was found in virgin paper chromatogram and the highest peak of DBP was found in sample C. In this study, DBP identification is done with full scan mode. Full scan is useful in determining unknown compounds in a sample. It provides more information than SIM when it comes to confirming or resolving compounds in a sample. During instrument method development it may be common to first analyze test solutions in full scan mode to determine the retention time and the mass fragment fingerprint before moving to a SIM instrument method (Lakshmi et al., 2013). Among various peaks appeared on chromatograms, DBP was identified at $20.6-20.7$ minutes of retention time.

In figure 3 , chromatogram showed that both of virgin and duplex papers contain a variety of components including DBP. However, virgin paper has a lower peak of DBP than duplex paper. This indicates that duplex paper contains more contaminants including DBP than virgin paper. The results of quantification also showed that the DBP concentration on virgin paper is lower than the five duplex papers. For paper and board packaging made from recycled materials, phthalates could also be carried over from the inks and adhesives on previous materials due to an incomplete removal during the recycling process (Cao, 2010).

\section{Migration of Di-N-Butyl Phthalate Into Food Simulant}

Direct food product contact with packaging has a higher migration rate than non-direct contact. The presence of an additional layer on the primary packaging will reduce the transfer of migrants into food products. However, nowadays food is often encountered packaged with paper packaging without additional layers so the possibility of DBP migration and other contaminants is very high. In addition, paper packaging is often used to pack oily food products. When evaluating the migration of phthalates, it is essential to consider the characteristics of the food. Phthalates are lipophilic and are found in higher concentrations in fatty foods (Moreira et al., 2014). In this study, the migration test used $95 \%$ ethanol as a food simulant to represent fatty foods (food type III, IV A, V, VII A and IX). Vegetable oil is not used as a food simulant because it so difficult to separate with dichloromethane when the extraction process. 95\% Ethanol can be used as food simulant for global migration tests (EU Directive 82/711/EC). DBP migration test was conducted only with samples that had the highest content of DBP (sample C). Migration test was conducted using single-side contact.

Migration test using food simulants is useful to identify DBP migration, but it does not really reflect the actual conditions. 95\% Ethanol is extractive, resulting in a DBP migration value that exceeds the true value.

According to Barnes et al. (2007), 95\% ethanol is more compatible in analytical methods but will provide a much higher migration value, so the results can be used as the worst case and the migration conditions remain realistic. 


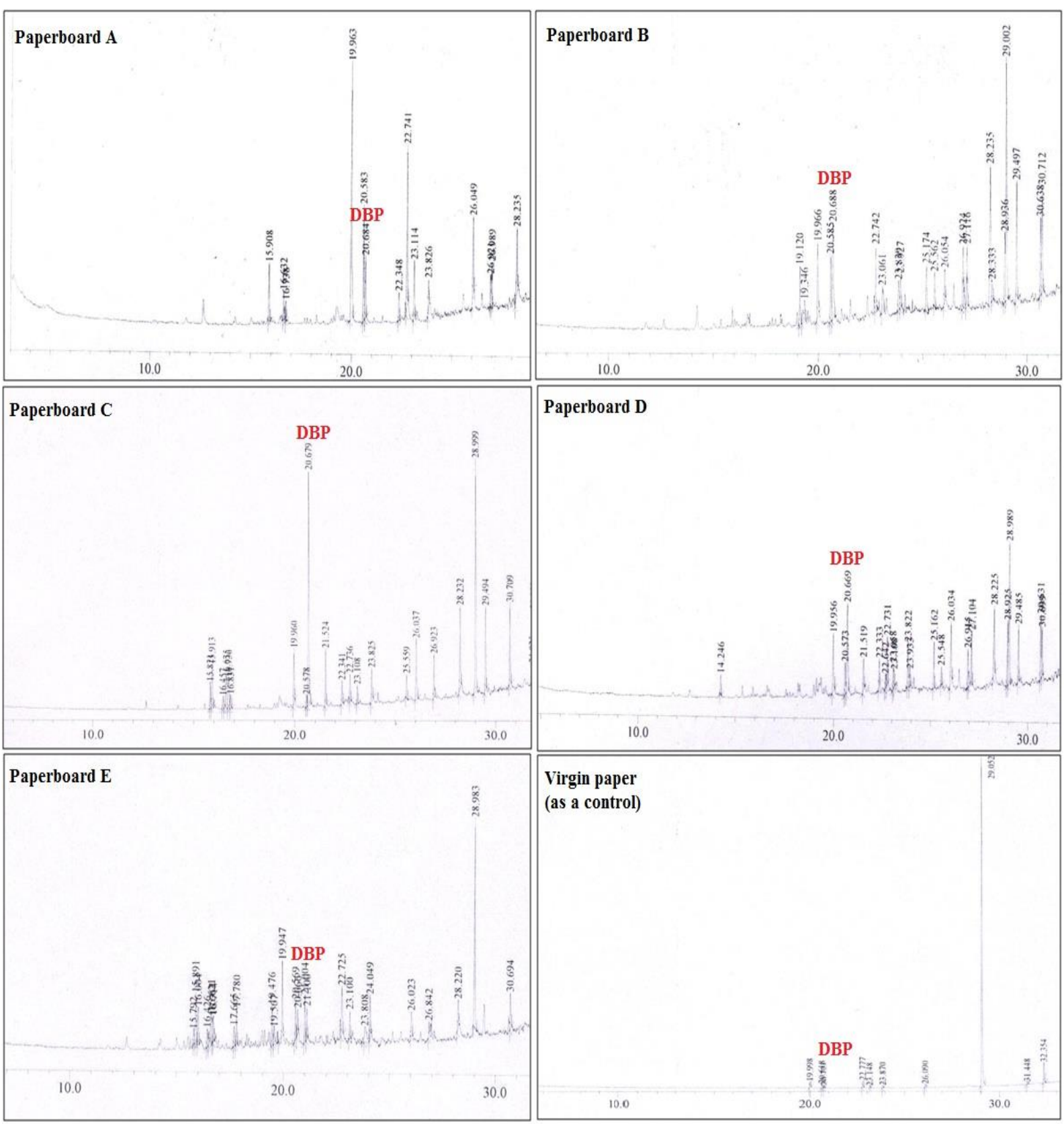

Figure 3. Representative chromatograms of recycled papers (A, B, C, D, and E) and virgin paper

The use of liquid food simulants on the paper migration test is less precise. This is because the liquid food simulants will be absorbed into all parts of the paper. In fact, the use of paper as primary packaging of solid food products does not occur immersion process, so the use of liquid food simulant actually less precise. The single-side contact method is more appropriately applied to paper-laminate plastic packaging or other coatings. Without a barrier, the DBP component on the duplex paper packaging will be extracted, so that the migration test results will be equivalent to the immersion system.

Table 4 showed DBP migration percentage of recycled papers in ethanol $95 \%$. DBP migration value was between $2.2-2.3 \mathrm{mg} / \mathrm{kg}$ or $4.6-4.8$ $\mathrm{mg} / \mathrm{dm}^{2}$. It exceeded DBP specific migration limit (SML) for packaging material recommended by EU Directive $2007 / 19 / \mathrm{EC}(0.3 \mathrm{mg} / \mathrm{kg}$ or equivalent to $0.05 \mathrm{mg} / \mathrm{dm}^{2}$ ). The migration of chemicals from polymers is a complex process and influenced by several factors such as the concentration of chemicals in packaging and food, type of food, temperature, and duration of contact (Bhunia et al., 2013). In addition, paper characteristics such as thickness, porosity, and recycled fiber content will affect the migration process (Zhang et al., 2008).

Based on the results of this research, DBP migration from recycled paper packaging into food materials needed more awareness from consumers. 
Table 4. Result of DBP migration test with ethanol $95 \%$ as food simulant

\begin{tabular}{lcccc}
\hline Replicates & $\begin{array}{c}\text { Initial } \\
\text { concentration } \\
(\mathbf{m g} / \mathbf{k g})\end{array}$ & $\begin{array}{c}\text { Migration } \\
(\mathbf{m g} / \mathbf{k g})\end{array}$ & $\begin{array}{c}\text { Migration } \\
\left(\mathbf{m g} / \mathbf{d m}^{2}\right)\end{array}$ & \% Migration \\
\hline 1 & 5.8 & 2.3 & 4.8 & 38.9 \\
2 & 5.8 & 2.3 & 4.8 & 38.9 \\
3 & 5.8 & 2.2 & 4.6 & 37.8 \\
\hline Mean & & & & 38.6 \\
SD & & & & 0.7 \\
\% RSD & & & 1.7 \\
\hline
\end{tabular}

Phthalates exposure into human body might cause complications for reproductive and nonreproductive health. Once consumed phthalates are rapidly metabolized in the gut, liver, and blood by esterase and lipases, because phthalate are lipophilic and low solubility in water (Hannon and Jodi, 2015). Therefore, recycled paper is not recommended to be used as primary packaging which has a direct contact with fatty food products.

\section{CONCLUSIONS AND RECOMENDATION}

\section{CONCLUSIONS}

The simple and fast method for the analysis of DBP in duplex paper based on ultrasonic assisted solvent extraction (USE) followed by GC-MS has been developed. The developed method was able to detect DBP at $0.04 \mathrm{mg} / \mathrm{kg}$ and to quantify DBP at $0.06 \mathrm{mg} / \mathrm{kg}$. The result of DBP migration study by using ethanol $95 \%$ as food simulant showed that the content of DBP in all commercial samples exceeded the limit recommended by EU. This study provides information that DBP can release and migrate into food that might impact the consumer's health. Therefore, the use of recycled paper as primary packaging which has direct contact with fatty food products is not recommended.

\section{RECOMMENDATION}

To confirm the results obtained in this experiment, it is recommended to conduct similar research using high-fat content food and measure the DBP migration e.g. DBP migration in cake and fried chicken served in duplex paper lunch box. It is also recommended to measure DBP migration in dried food which is packed in duplex paper as secondary packaging such as milk powder or breakfast cereal.

\section{REFERENCES}

AOAC. 2012. Guidelines for single laboratory validation of chemical method for dietary supplements and botanical. Association of Official Analytical Chemists.

.APVMA. 2004. Guidelines for the validation of analytical methods for active constituent, agricultural and veterinary chemical products. Australian Pesticides and Veterinary Medicines Authority.
Barnes KA, Richard S, and Watson DH. 2007. Chemical Migration and Food Contact Material. 219-232. North America:CRC Press LLC.

Bhunia K, Shyam SS, Juming T, Barbara R. 2013. Migration of chemical compounds from packaging polymers during microwave, conventional heat treatment, and storage. Comprehensive Reviews in Food Science and Food Safety 12:523-545. DOI: 10.1111/15414337.12028

Binderup ML, Pedersoen GA, Vinggaard AM, Rasmussen ES, Rosenquist H, Cederberg T. 2002. Toxicity testing and chemical analysis of recycled fiber based paper for food contact. Food Additives \& Contaminants. 25(19):13-28.

Cao XL. 2010. Phthalate ester in foods: sources, occurrence, and analytical methods. Comprehensive Review in Food Science and Food Safety. 9(1):21-42.

EFSA. 2005. Opinion of the Scientific Panel on food additives, flavorings, processing aids and materials in contact with food (AFC) related to di-butyl phthalate (DBP) for use in food contact materials. European Food Safety Authority Journal. 242:1-17. DOI:10.2903/ j.efsa.2005.242

EU. 1982. Commission Directive 82/711/EEC of 18 October 1982. Laying down the list of simulants to be used for testing migration of constituents of plastic materials and article intended to come into contact with foodstuff. European Union. Official Journal of the European Union L 297, 23 October 1982, pp 26-30.

EU. 2007. Commission Directive 2007/19/EC amending Directive 2002/72/EC. Plastic materials and articles intended to come into contact with food. European Union. Official Journal of the European Union L 91, 31 March 2007, pp 26-30.

Fitria LS, Yanto DH, Laksana RP, Kurniawan YD, Fatriasari W, Hermiati E. 2018. Potential of mineral oil migration from recycle paper based packaging into food. Conference Proceedings of the Korean Society of Wood Science (1):48. The Korean Society of Wood Science and Technology Annual Meeting. Gyeongnam 
National University of Science and Technology, Gyeongnam , Korea. $13^{\text {th }}-14^{\text {th }}$ April 2018.

Hannon PR and Flaws JA. 2015. The effects of phthalates on the ovary. Front Endocrinol 6(8):1-19. DOI: 10.3389/fendo.2015.00008

Huber L. 2007. Validation and Qualification in Analytical Laboratories. New York, USA: Informa Healthcare.

Jamnicki S, Branka L, Vera R, Lidija B. 2012. A study on the food contact suitablity of recycled paper and board. Research, development, technology-Papíripar. LVI(4): 14-19.

Lakshmi HB, Angala PS, and Gopinath C. 2013. A review on GC-MS method development and validation. International Journal Pharmaceutical Quality Assurance. 4(3):4251.

Lara NLM, Sander van den D, Sheila M, Luis RF, Richard MS. 2017. Dibutyl phthalate induced testicular dysigenesis origanates after seminiferous cord formation in rats. Scientific reports. 7:2521. DOI: 10.1038/s45198-01702684-2.

Marsh K and Betty B. 2007. Food packaging-roles, materials, and environtment issues. Journal Food Science. 72(3):39-55. DOI: 10.1111/j.1750-3841.2007.0031.x.

Milojkovic DS, Darko HA, Gordana MK, Tatjana DA. 2015. Evaluation of a method for phthalate extraction from milk related to the milk dilution ratio. Journal Serbian Chemical Society. 80 (8) : 983-996.

Moreira MA, Leiliane CA, and Zenilda LC. 2014. Analysis of phthalate migration to food simulants in plastic containers during microwave operations. International Journal Environmental Research and Public Health. 11:507-526.

Pace GV and Hartman TG. 2010. Migration studies of 3-chloro-1,2-propanediol in polyethylene extrusion-coated paperboard food packaging. Food Additives \& Contaminants. 27(6) : 844891.
Parigoridi IE, Demertzi KA, and Demertzis PG. 2014. Determination of five (5) possible contaminants in recycled cardboard packages and food simulants using ultrasound assisted extraction coupled to GC-MS. Material Science Applied. 5:745-751. DOI: 10.4236/msa.2014.510075.

Song YS, Hong JP, and Vanee K. 2002. Analytical procedure for quantifying five compounds suspected as possible contaminants in recycled paper/paperboard for food packaging. Journal Agricultural and Food Chemistry. 48:5856-5859. DOI: 10.1021/jf000512x.

Suciu NA, Fransesca T, Sotirios V, Lucrezia L, Marco T. 2013. Recycled paper-paperboard for food contact materials: Contaminants suspected and migration into foods and food simulant. Food Chemical. 141:4146-4151.

Vapenka L, Adam V, Lenka V, Kristina K, Jaroslav D, Jitka S. 2016. Contaminants in the paperbased food packaging materials used in the Czech Republic. Journal Food and Nutrition Research. 55(4):361-373.

Wei CK, Loke CF, and Michelle P. 2014. Determination of six phthalates in polypropylene consumer products by sonication-assisted extraction/gc-ms methods. Malaysian Journal Analytical Sciences. 15(2): $167-174$.

Wenzl T. 2009. Methods for the Determination of Phthalates in Food. 7-8. [Scientific and Technical Reports]. JRC European Commission Joint Research Centre, European Commission, Belgium. DOI: 10.2787/1406.

Zhang K, Noonan GO, and Begley TH. 2008. Determination of 2,6-di-isopropylnaphthalene (DIPN) and n-dibutylphthalate (DBP) in food and paper packaging materials from US market places. Food Additives \& Contaminants. 25(11):1416-1423. DOI: 10.1080/026520 30802163380 . 